\title{
Absence of FMLP Receptors on Rat Macrophages
}

\author{
Blair A.M. Walker, Andrew J. Seiler, Catherine A. Owens, \\ Brian E. Hagenlocker, and Peter A. Ward \\ The University of Michigan Medical School, Department of Pathology, Ann Arbor
}

\begin{abstract}
Although rat peritoneal neutrophils in the presence of cytochalasin $B$ demonstrate superoxide $\left(\mathrm{O}_{2}{ }^{-}\right)$responses to the chemotactic peptide $\mathrm{N}^{\prime}$-formyl-met-leu-phe (FMLP), neither elicited rat pertitoneal macrophages nor rat alveolar macrophages show an $\mathrm{O}_{2}{ }^{-}$ response to FMLP (in the presence or absence of cytochalasin B), although a good $\mathrm{O}_{2}{ }^{-}$ response to opsonized zymosan is demonstrated by both types of macrophages. Using Fura-2 loaded cells, pertitoneal macrophages failed to show an increase in intracellular calcium after exposure to FMLP, f-nor-lou-phe, F-met-met-met, or F-norleu-leu-phenorleu-lys. FMLP also falled to Induce elevations in intracellular calcium in alveolar macrophages. In ${ }^{3}$ H-FMLP binding studies, the lack of responsiveness of peritoneal and alveolar macrophages was associated with the lack of FMLP receptors on these cell types, in striking contrast to the presence of functional receptors on rat neutrophils.
\end{abstract}

Key words: chemotactic peptide, intracellular calcium, superoxide anion, rat

\section{INTRODUCTION}

The discovery that bacterial culture supernatants are chemotactic for leukocytes [49] led to the isolation and characterization of small $\mathrm{N}$-formylated chemotactic peptides. Formyl-met-leu-phe (FMLP) has become the most widely studied of these peptides [38,39]. FMLP also has been shown to cause enzyme release $[3,6,12]$, upmodulation of leukocyte adhesion molecules $[15,34,46]$, priming [5], and direct stimulation of the superoxide response $[3,6,9,12,38]$ in a variety of cells including neutrophils, monocytes, macrophages, and eosinophils. FMLP receptors have been characterized on human [51], rat [29], rabbit [1], and horse [42] neutrophils, human monocytes [7], and guinea pig macrophages $[8,43]$. The FMLP receptor is a classical guanine nucleotide binding protein (g-protein) linked receptor [4], occupancy of which leads to phospholipase activation and elevations in intracellular inositol 1,4,5-trisphosphate $\left[\operatorname{Ins}(1,4,5) \mathrm{P}_{3}\right][10,11]$, diacylglyerol $[23,26]$, intracellular $\mathrm{Ca}^{2+}[25]$, and cyclic adenosine monophosphate (cAMP) [41].

Recently, we have observed that FMLP was incapable of eliciting superoxide responses or elevations in cytosolic $\mathrm{Ca}^{2+}$ in rat alveolar macrophages whereas blood and peritoneal neutrophils were fully responsive [21]. Because of these observations, rat alveolar macrophages and elicited rat peritoneal macrophages, both of which failed to demonstrate $\mathrm{O}_{2}{ }^{-}$responses after stimulation with FMLP, were examined for evidence of FMLP receptors. Using the changes in intracellular $\mathrm{Ca}^{2+}$ concentration $\left(\left[\mathrm{Ca}^{2+}\right]_{i}\right)$ as a sensitive indicator of receptorligand interaction, no relevant response to FMLP or other formyl peptides was demonstrated in rat macrophages.
Failure to respond can be ascribed to a lack of surface receptors for FMLP. These data have implications for the use of FMLP in studies of the inflammatory response in experimental animals.

\section{MATERIALS AND METHODS Agonists}

Unless otherwise specified, reagents were purchased from Sigma Chemical Co. (St. Louis, MO). N'-FMLP, $\mathrm{N}^{\prime}$-formyl-norleu-leu-phe (FNLP), $\mathrm{N}^{\prime}$-formyl-met-metmet (FMMM), and $\mathrm{N}^{\prime}$-formyl-norleu-leu-phe-norleu-tyrlys (FNLPNTK) were stored at $2 \mathrm{mM}$ in dimethyl sulfoxide (DMSO) and diluted in Hanks' balanced salt solution (HBSS) when needed. Plasma opsonized zymosan (POZ) was prepared by incubating boiled zymosan

Abbreviations: FMLP, formyl-met-leu-phe; $\left[{ }^{3} \mathrm{H}\right]$ FMLP, formyl-metleu- $\left[{ }^{3} \mathrm{H}\right]$ phe; FNLP, formyl-norleu-leu-phe; FMMM, formyl-met-metmet; FNLPNTK, formyl-norleu-leu-phe-norleu-tyr-lys; ins $(1,4,5) \mathrm{P}_{3}$, inositol 1,4,5-trisphosphate; HBSS, Hanks' balanced salt solution; PAF, platelet activating factor; POZ, plasma opsinized zymosan; PBS, phosphate buffered saline; Fura-2/AM, acetoxymethyl ester of Fura-2; $\left[\mathrm{Ca}^{2+}\right]_{i}$, intracellular $\mathrm{Ca}^{2+}$ concentration; $\mathrm{K}_{\mathrm{D}}$, dissociation constant; EGTA, ethyleneglycol-bis( $\beta$-amino-ethyl ether)- $N, N, N^{\prime}, N^{\prime}$-tetraacetate acid; g-protein, guanine nucleotide binding protein; cAMP, cyclic adenosine monophosphate; DMSO, dimethyl sulfoxide; SOD, superoxide dismutase; PMA, phorbol myristate acetate.

Received January 16, 1991; accepted April 5, 1991.

Reprint requests: Peter A. Ward, The University of Michigan Medical School, Department of Pathology, 1301 Catherine Street, Box 0602, Ann Arbor, MI 48109-0602. 
with fresh heparinized rat plasma at $37^{\circ} \mathrm{C}$ for $30 \mathrm{~min}$, followed by centrifugation and washing prior to use. Platelet activating factor (PAF, 1-0-alkyl-2-acetyl-SNglyceryl-3-phosphorycholine, $2 \mathrm{mg} / \mathrm{ml}$ ), was stored in $\mathrm{CHCl}_{3}$ and dried under nitrogen prior to use. Formylmet-leu- $\left[{ }^{3} \mathrm{H}\right]$ phe $\left(\left[{ }^{3} \mathrm{H}\right]\right.$ FMLP) was purchased from Amersham Corp. (Arlington Heights, IL).

\section{Preparation of Rat Alveolar Macrophages and Peritoneal Neutrophils}

Sprague Dawley retired breeder rats $(300-500 \mathrm{~g})$ were used for all experiments. Peritoneal macrophages were elicited by the injection of autoclaved $10 \%$ (wt/vol) sodium caseinate in pyrogen-free $0.9 \%(\mathrm{wt} / \mathrm{vol})$ sodium chloride solution (Abbott Laboratories, Chicago, IL). Cells were harvested 3-6 days later by peritoneal lavage with $50 \mathrm{ml}$ of heparinized $(1 \mathrm{U} / \mathrm{ml})$ sodium chloride solution. Macrophages were further purified on percoll gradients by mixing $3.4 \mathrm{ml}$ cells in phosphate buffered

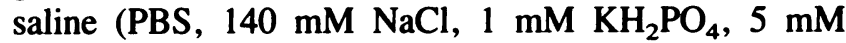
$\mathrm{NaPO}_{4}$, pH 7.3), with $6.8 \mathrm{ml}$ of modified percoll solution (specific gravity 1.099 containing: $0.61 \mathrm{ml} 1.5 \mathrm{M} \mathrm{NaCl}$, $1.201 \mathrm{ml} \mathrm{H}_{2} \mathrm{O}$, and $4.88 \mathrm{ml}$ of percoll [Pharmacia LKB, Uppsala, Sweden]). The mixture was centrifuged at $2,000 \mathrm{~g}$ for $20 \mathrm{~min}$. Cells were harvested from the top of the gradient and washed twice in PBS prior to use. Alveolar macrophages were obtained by bronchoalveolar lavage using $7 \mathrm{ml}$ sterile saline (at $37^{\circ} \mathrm{C}$ ) for each of seven lavages. This resulted in a cell yield of $6-7 \times 10^{6}$ macrophages per animal. Peritoneal neutrophils were elicited by the injection of $1 \%$ glycogen for $4-16 \mathrm{~h}$ and the cells recovered by peritoneal lavage. Neutrophils were washed once with PBS and used without further purification. To obtain rat peripheral blood neutrophils, heparinized whole blood diluted 1:1 with PBS was layered onto Ficoll-hypaque (specific gravity 1.077), centrifuged $(400 \mathrm{~g}, 30 \mathrm{~min})$, and the red blood cell layer containing the neutrophils incubated in a lysing solution of $\mathrm{NH}_{4} \mathrm{Cl}$. The neutrophils were then washed and resuspended in HBSS. Differential counts using crystal violet staining of the nuclei were performed in each case. Typical results of the cell content of the various preparations are shown in Table 1.

\section{Measurement on Intracellular Calcium Changes}

Rat macrophages and neutrophils were loaded with the acetoxymethyl ester of Fura-2 (Fura-2/AM) (acetoxymethyl ester) (Calbiochem, La Jolla, CA) by suspending cells in $5 \mu \mathrm{M}$ Fura-2/AM for $15 \mathrm{~min}$ at $37^{\circ} \mathrm{C}$ then diluted $1: 10$ and incubated for an additional $15 \mathrm{~min}$. After loading, cells were centrifuged and resuspended in HBSS and stored on ice. Just prior to use, aliquots were centrifuged $(450 \mathrm{~g}, 3 \mathrm{~min})$ and the cells resuspended in HBSS.
TABLE 1. Purity of Cell Preparations"

\begin{tabular}{lccc}
\hline & \multicolumn{3}{c}{ Cell content (\% of total) } \\
\cline { 2 - 4 } Preparation & $\begin{array}{c}\text { Mononuclear } \\
\text { phagocytes }\end{array}$ & Neutrophils & Others $^{\mathrm{b}}$ \\
\hline Peritoneal macrophages & $90 \pm 2$ & $3 \pm 2$ & $7 \pm 2$ \\
Alveolar macrophages & $97 \pm 2$ & $1 \pm 1$ & $2 \pm 1$ \\
Blood neutrophils & $17 \pm 4$ & $74 \pm 4$ & $4 \pm 2$ \\
Peritoneal neutrophils & $4 \pm 3$ & $95 \pm 2$ & $1 \pm 2$ \\
\hline
\end{tabular}

a Based on differential counts of crystal violet stained nuclei.

${ }^{b}$ Mainly lymphocytes.

Changes in $\mathrm{Ca}^{2+}$-dependent fluorescence were measured in a Perkin Elmer LS-50 luminescence spectrometer using a thermally equilibrated cuvette holder at $37^{\circ} \mathrm{C}$, with dual excitation wave lengths of 340 and $380 \mathrm{~nm}$ and the emission wave length of $500 \mathrm{~nm}$. $\left[\mathrm{Ca}^{2+}\right]_{i}$ were determined using the equation described by Grynkiewiez et al. [20] where Fmax represents the maximum fluorescence following the lysis of cells with $0.2 \%$ Triton $\mathrm{X}-100$, and Fmin represents the fluorescence following the addition of EGTA ( $10 \mathrm{mM}, \mathrm{pH} 10.5)$.

\section{Measurement of Superoxide Responses}

Generation of superoxide anion $\left(\mathrm{O}_{2}^{-}\right)$was determined by the superoxide dismutase (SOD) inhibitable reduction of ferricytochrome $c$ as described previously [48]. Prewarmed cells were added to a reaction mixture containing ferricytochrome c $(80 \mu \mathrm{M})$ and agonist with or without SOD $(85 \mathrm{U} / \mathrm{ml})$. The difference in reduction of ferricytochrome $c$ in the presence and absence of SOD, as determined spectrophotometrically at $550 \mathrm{~nm}$, was measured and superoxide production calculated as described previously [48].

\section{[ $\left.{ }^{3} \mathrm{H}\right]$ FMLP Binding}

Cells were suspended in PBS containing $1.8 \mathrm{mM}$ $\mathrm{Ca}^{2+}, 0.8 \mathrm{mM} \mathrm{Mg}^{2+}$, and $1 \mathrm{mM}$ phenylmethylsulfonyl fluoride. For $\left[{ }^{3} \mathrm{H}\right] \mathrm{FMLP}$ binding, $100 \mu \mathrm{l}\left(10^{6}\right)$ cells were incubated with $25 \mu$ l of $\left[{ }^{3} \mathrm{H}\right] \mathrm{FMLP}(0.5-30 \mathrm{nM})$ and 25 $\mu l$ of either buffer or cold FMLP (final concentration 10 $\mu \mathrm{M})$. After equilibration for $45 \mathrm{~min}$ at $4^{\circ} \mathrm{C}$, cells were harvested by rapid vacuum filtration over glass fiber filters (Whatman GF/C, Whatman International, Maidstone, United Kingdom) and washed with $16 \mathrm{ml}$ of ice cold PBS containing calcium and magnesium. Filters were then put into scintillation vials, dried overnight, and $5 \mathrm{ml}$ of scintillation fluid was added (Biosafe II, Research Products International, Mount Pleasant, IL) and assessed in a Beckman LS 5000TD scintillation counter (Fullerton, CA). Scatchard curves were plotted with the aid of the program EBDA (Elsevier-Biosoft, Cambridge, United Kingdom). 


\section{Statistical Analysis}

As indicated in the text or Figure legends, the number (n) of separate experiments from which the data were derived is listed. Data were expressed as mean (x) \pm 1 standard error of the mean (SE). Statistical significance was defined as $P<0.05$.

\section{RESULTS}

\section{FMLP Responses of Rat Neutrophils and Macrophages}

In order to assess the $\mathrm{O}_{2}{ }^{-}$responses of rat neutrophils and macrophages to FMLP, glycogen-elicited peritoneal neutrophils, peripheral blood neutrophils, alveolar macrophages, and casein-elicited peritoneal macrophages were exposed to HBSS, FMLP $(1 \mu \mathrm{M})$, and POZ $(1 \mathrm{mg} / \mathrm{ml})$ (Fig. 1). Since it has been shown previously that rat neutrophils require the presence of cytochalasin B for reliable $\mathrm{O}_{2}{ }^{-}$responses $[27,50]$, blood and peritoneal neutrophils were stimulated in the presence of $2.5 \mu \mathrm{M}$ cytochalasin $B$. In the absence of cytochalasin $B$, the responses of peripheral blood neutrophils to FMLP were $<2.5 \mathrm{nmol} \mathrm{O}_{2}^{-} / 30 \mathrm{~min} / 10^{6}$ cells, barely above the negative control $\left(1.18 \pm 0.41 \mathrm{nmol} \mathrm{O}_{2}{ }^{-}\right)$consistent with our earlier findings [33].

Both peritoneal and alveolar macrophages were unresponsive to $1 \mu \mathrm{M}$ FMLP (Fig. 1B). With peritoneal macrophages there was failure of the cells to respond to FMLP whether or not cytochalasin B was present, while the $\mathrm{O}_{2}{ }^{-}$response to $\mathrm{POZ}$ was unaffected by the addition of cytochalasin B (Fig. 1B). In the absence of cytochalasin B, alveolar macrophages had higher background levels of $\mathrm{O}_{2}{ }^{-}$production $\left(3.90 \pm 0.07 \mathrm{nmol} / 30 \mathrm{~min} / 10^{6}\right.$ cells), and the response to FMLP was similar to the background value $\left(3.68 \pm 0.39 \mathrm{nmol} \mathrm{O}_{2}{ }^{-}\right)$(Fig. 1B). The addition of cytochalasin $\mathrm{B}$ to alveolar macrophages resulted in somewhat lower background and FMLP values of $\mathrm{O}_{2}{ }^{-}(2.21 \pm 0.44$ and $1.62 \pm 0.05 \mathrm{nmol}$, respectively) (data not shown). In a companion experiment, in the absence or presence of cytochalasin $B$, the $\mathrm{POZ}$ responses were $7.97 \pm 0.05$ and $8.09 \pm 0.69 \mathrm{nmol}$ $\mathrm{O}_{2}{ }^{-}$, respectively (data not shown), indicating that cytochalasin $\mathrm{B}$ does not enhance $\mathrm{O}_{2}{ }^{-}$response of alveolar macrophages, a finding consistent with our earlier studies [18,33]. Over a wide dose range of FMLP $(100$ OnM-5 $\mu \mathrm{M})$, production of $\mathrm{O}_{2}^{-}$by peritoneal macrophages was not different from unstimulated cells incubated in HBSS ( $n=5$, data not shown). The presence of cytochalasin B did not enhance the response to either agonist, similar to earlier findings [50]. This stands in contrast to the enhancing effects of cytochalasin B on production of $\mathrm{O}_{2}^{-}$in blood and peritoneal neutrophils (Fig. 1A).
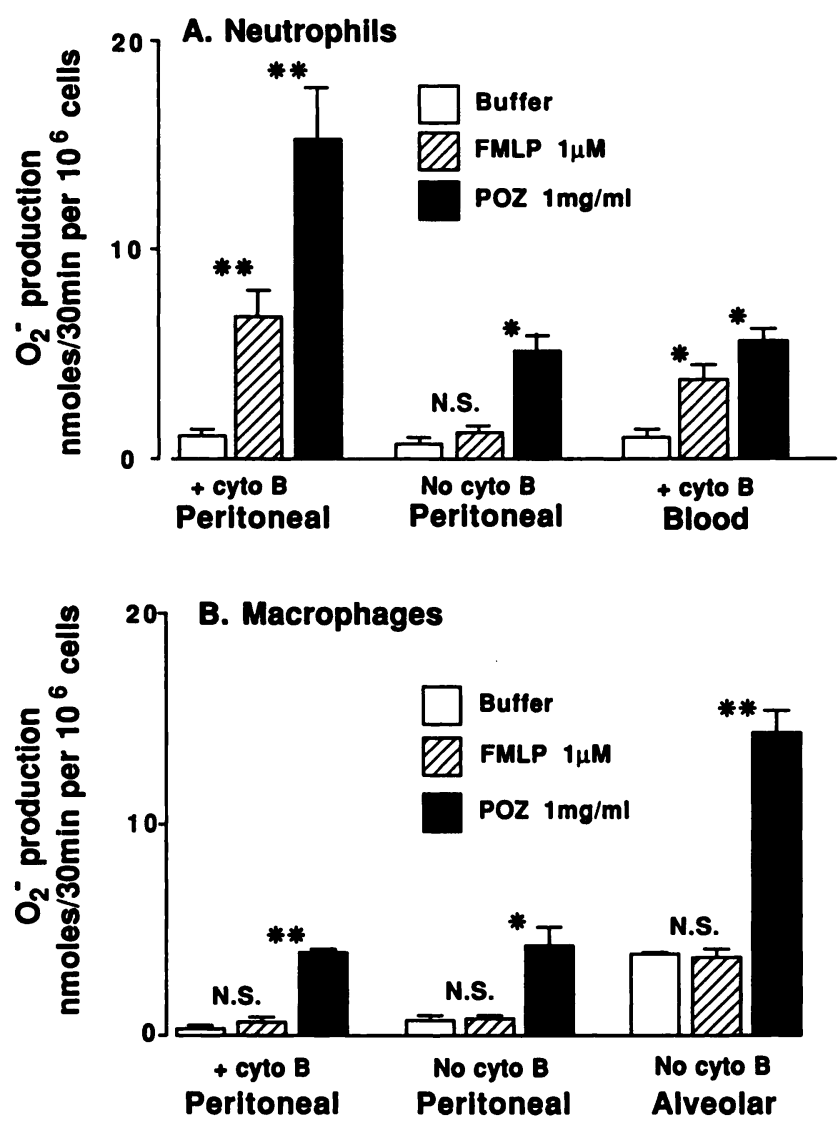

Fig. 1. $\mathrm{O}_{2}^{-}$responses of glycogen-elicited peritoneal neutrophils and peripheral blood neutrophils (A), and casein-elicited peritoneal macrophages or alveolar macrophages (B) following the addition of HBSS, FMLP, or POZ. Responses were measured in the presence (+cyto B) or absence (no cyto B) of $2.5 \mu \mathrm{M}$ cytochalasin B. ${ }^{*} P<0.05, * P<0.005$, N.S., not significant, each compared to buffer control alone ( $n=4$ for all conditions except peritoneal neutrophils with cytochalasin B where $n=6$ ).

\section{Changes in Cytosolic $\mathrm{Ca}^{2+}$ Following Exposure to Formyl Peptides}

In neutrophils, exposure to FMLP results in changes in cytosolic $\mathrm{Ca}^{2+}$ that occur (in the absence of cytochalasin B) at concentrations that are 10 to 100 fold lower than those necessary for $\mathrm{O}_{2}^{-}$responses $[25,37]$. Therefore changes in $\left[\mathrm{Ca}^{2+}\right]_{\mathrm{i}}$ serve as a sensitive indicator for receptor occupancy in g-protein/phospholipase $\mathrm{C}$ linked receptors. Accordingly, cytosolic $\mathrm{Ca}^{2+}$ concentrations were measured in Fura-2 loaded neutrophils and macrophages. The results are summarized in Table 2 where maximal changes in $\left[\mathrm{Ca}^{2+}\right]_{i}$ are indicated after addition of agonist. The addition of FMLP $(1 \mu \mathrm{M})$ or PAF (10 $\mu \mathrm{M})$ to neutrophils or addition of PAF $(10 \mu \mathrm{M})$ to macrophages resulted in a rapid rise in cytosolic $\mathrm{Ca}^{2+}$ that peaked within the first $30 \mathrm{sec}$ (data not shown). Table 2 shows the resting $\left[\mathrm{Ca}^{2+}\right]_{i}$ and the peak cytosolic $\mathrm{Ca}^{2+}$ 
TABLE 2. Effects of Formylated Peptides and PAF on Intracellular $\mathrm{Ca}^{2+}$ Levels in Rat Neutrophils and Macrophages

\begin{tabular}{|c|c|c|c|c|}
\hline \multirow[b]{2}{*}{$\begin{array}{l}\text { Agonist } \\
\text { employed }^{\text {a }}\end{array}$} & \multirow[b]{2}{*}{$\begin{array}{c}\text { Intracellular } \\
\mathrm{Ca}^{2+}\end{array}$} & \multicolumn{3}{|c|}{ Peak level of intracellular $\mathrm{Ca}^{2+}(\mathrm{nM})^{b}$} \\
\hline & & $\begin{array}{l}\text { Peritoneal } \\
\text { neutrophils }\end{array}$ & $\begin{array}{c}\text { Peritoneal } \\
\text { macrophages }\end{array}$ & $\begin{array}{c}\text { Alveolar } \\
\text { macrophages }\end{array}$ \\
\hline PAF, $10 \mu \mathrm{M}$ & $\begin{array}{l}\text { Basalc }^{c} \\
\text { Peak }^{c}\end{array}$ & $\begin{aligned} 82 & \pm 29 \\
304 & \pm 9 \\
(P & <0.005)^{*}\end{aligned}$ & $\begin{array}{l}129 \pm 5 \\
402 \pm 7 \\
\quad(P<0.005)\end{array}$ & $\begin{array}{l}106 \pm 11 \\
308 \pm 44 \\
\quad(P<0.005)\end{array}$ \\
\hline FMLP, $1 \mu \mathrm{M}$ & $\begin{array}{l}\text { Basal } \\
\text { Peak }\end{array}$ & $\begin{array}{l}104 \pm 28 \\
323 \pm 29 \\
(P<0.05)\end{array}$ & $\begin{array}{c}130 \pm 13 \\
143 \pm 12 \\
(P, \text { N.S. })\end{array}$ & $\begin{array}{l}106 \pm 11 \\
116 \pm 14 \\
\quad(P<0.05)\end{array}$ \\
\hline FNLP, $1 \mu \mathrm{M}$ & $\begin{array}{l}\text { Basal } \\
\text { Peak }\end{array}$ & $\begin{aligned} 94 & \pm 33 \\
320 & \pm 45 \\
(P & <0.05)\end{aligned}$ & $\begin{array}{c}136 \pm 11 \\
141 \pm 13 \\
(P, \text { N.S. })\end{array}$ & $\mathrm{ND}^{\mathrm{d}}$ \\
\hline FMMM, $1 \mu \mathrm{M}$ & $\begin{array}{l}\text { Basal } \\
\text { Peak }\end{array}$ & $\begin{array}{l}105 \pm 27 \\
303 \pm 43 \\
(P<0.05)\end{array}$ & $\begin{array}{c}118 \pm 5 \\
129 \pm 5 \\
(P, N . S .)\end{array}$ & ND \\
\hline FNLPNTK, $1 \mu \mathrm{M}$ & $\begin{array}{l}\text { Basal } \\
\text { Peak }\end{array}$ & $\begin{array}{c}95 \pm 34 \\
272 \pm 46 \\
(P<0.05)\end{array}$ & $\begin{array}{c}121 \pm 8 \\
126 \pm 9 \\
(P, \text { N.S. })\end{array}$ & ND \\
\hline
\end{tabular}

${ }^{\text {a } P A F, ~ p l a t e l e t ~ a c t i v a t i n g ~ f a c t o r ~(s e e ~ a b o v e) ; ~ F M L P, ~} \mathrm{~N}^{\prime}$-formyl-met-leu-phe; FNLP, $\mathrm{N}^{\prime}$-formylnorleu-leu-phe; FMMM, N'-formyl-met-met-met; FNLPNTK, $\mathrm{N}^{\prime}$-formyl-norleu-leu-phenorleu-tyr-lys.

${ }^{b}$ As measured by intracellular calcium-dependent Fura-2 fluorescence.

c Basal intracellular $\mathrm{Ca}^{2+}$ prior to addition of agonist; peak $\mathrm{Ca}^{2+}$ reflects highest intracellular $\mathrm{Ca}^{2+}$ concentration following addition of agonist.

${ }^{d} \mathrm{ND}$, not done.

* $P$ values, comparing basal to peak intracellular $\mathrm{Ca}^{2+}$ levels. N.S., not significant $(P>0.05)$.

concentration occurring within $30 \mathrm{sec}$ after addition to Fura-2 loaded peritoneal neutrophils and macrophages of $1 \mu \mathrm{M}$ of each of the following formylated peptides: FMLP, FNLP, FNLPNTK, and FMMM. The first three have been shown to be potent chemotactic peptide receptor ligands in neutrophils and macrophages of other species $[2,31,53]$. PAF $(10 \mu \mathrm{M})$ was used as a reference agonist. The addition to neutrophils of each of the formyl peptides resulted in elevations in cytosolic $\mathrm{Ca}^{2+}$, ranging from $323 \pm 29$ to $273 \pm 46 \mathrm{nM}$, levels that were similar to the maximal neutrophil response to PAF (304 \pm 29 nM). In contrast, in macrophages exposed to formyl peptides $\left[\mathrm{Ca}^{2+}\right]_{\mathrm{i}}$ rose by $1 \%$ to $10 \%$, but these were not statistically significant $(n=4)$.

Similar experiments were performed with alveolar macrophages. Because of the limits in the number of cells available for these studies, calcium measurements were limited to the agonists, FMLP $(1 \mu \mathrm{M})$ and PAF $(10 \mu \mathrm{M})$. The resting and peak increases in the $\left[\mathrm{Ca}^{2+}\right]_{\mathrm{i}} 30 \mathrm{sec}$ following the addition of FMLP are described in Table 2. When resting $\left[\mathrm{Ca}^{2+}\right]_{i}$ was compared to that obtained 30 sec after the addition of FMLP to alveolar macrophages, there was an extremely small but a statistically significant rise in $\left[\mathrm{Ca}^{2+}\right]_{i}$ (of $\left.11 \mathrm{nM}\right)$ above resting $\left[\mathrm{Ca}^{2+}\right]_{i}(\mathrm{n}=8)$. This was, however, entirely attributable to a small upward drift in $\mathrm{Ca}^{2+}$-dependent fluorescence due to leakage of Fura-2 from cells (data not shown). In each of eight experiments the slope of the fluorescence tracing during the prestimulatory period was equal to the slope following the addition of FMLP (data not shown). These data indicate that alveolar macrophages do not mobilize intracellular $\mathrm{Ca}^{2+}$ in response to FMLP, in contrast to their ability to respond to PAF.

\section{$\left[{ }^{3} \mathrm{H}\right]$ FMLP Binding to Rat Neutrophils and Macrophages}

Having established that rat peritoneal and alveolar macrophages lack the functional and biochemical responses associated with cell activation by FMLP, experiments were performed to determine if receptor specific binding could be detected on macrophages. Figure 2 shows the $\left[{ }^{3} \mathrm{H}\right] \mathrm{FMLP}$ binding to $10^{6}$ cells in the presence and the absence of an excess of cold FMLP, permitting calculation of nonspecific and total $\left[{ }^{3} \mathrm{H}\right] \mathrm{FMLP}$ binding. The difference between the total and nonspecific binding under these conditions is by convention indicative of specific binding to surface receptors. In Figure 2A, peritoneal neutrophils showed a concentration-dependent increase in $\left[{ }^{3} \mathrm{H}\right] \mathrm{FMLP}$ binding. Receptor specific binding represented $73 \%$ of the total binding at the highest 


\section{A. Peritoneal Neutrophils}
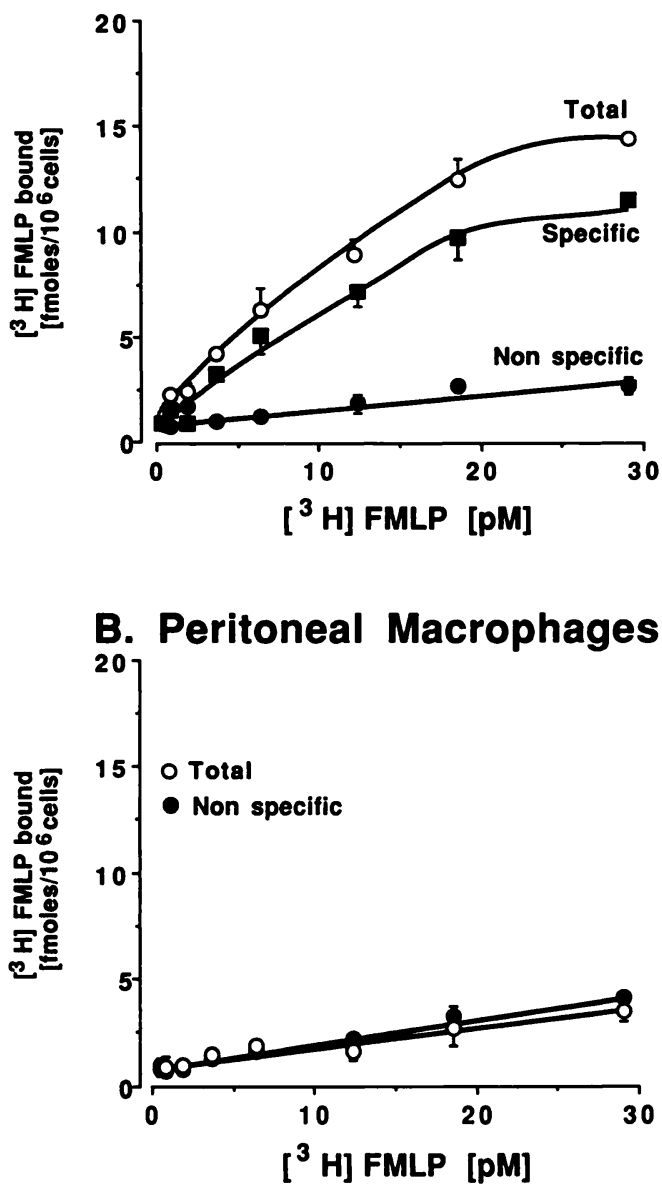

Fig. 2. [ $\left.{ }^{3} \mathrm{H}\right] \mathrm{FMLP}$ binding to peritoneal neutrophils $(A)$ and peritoneal macrophages (B) in the presence (total binding) or absence (nonspecific binding) of $10 \mu \mathrm{M}$ unlabeled FMLP. Each point represents the $x \pm 1$ standard deviation of triplicate determinations from a single experiment. One femtomole of [ $\left.{ }^{3} \mathrm{H}\right]$ FMLP $=110 \mathrm{dpm}$. Results are representative of three separate experiments.

concentration of FMLP (30 nM). Scatchard analysis of these data showed a $K_{D}$ of $16.8 \mathrm{nM}$, with 10,991 receptors per cell. Under identical conditions, peritoneal macrophages showed no difference between total and nonspecific binding over $\left[{ }^{3} \mathrm{H}\right] \mathrm{FMLP}$ concentrations of 0.5-30 nM (Fig. 2B). Actual binding data as well as statistical comparisons of $\left[{ }^{3} \mathrm{H}\right] \mathrm{FMLP}$ binding at $12 \mathrm{nM}$ $\left[{ }^{3} \mathrm{H}\right]$ FMLP for neutrophils, peritoneal macrophages, and alveolar macrophages are shown in Table 3. Unlike neutrophils, peritoneal and alveolar macrophages showed no difference between total and nonspecific binding and thus, no evidence of receptor binding. Therefore, the lack of functional and biochemical responses to FMLP in
TABLE 3. $\left[{ }^{3} \mathrm{H}\right] F$ MLP Binding to Rat Neutrophils and Macrophages

\begin{tabular}{lccc}
\hline & & \multicolumn{2}{c}{$\left[{ }^{3} \mathrm{H}\right]$ FMLP } \\
\cline { 3 - 4 } Cells tested & $\mathrm{n}^{\mathrm{b}}$ & Nonspecific & Total \\
\hline Alveolar macrophages & 3 & $82 \pm 2$ & $86 \pm 5$ (N.S.) \\
Peritoneal macrophages & 6 & $171 \pm 38$ & $171 \pm 23$ (N.S.) \\
Peritoneal neutrophils & 6 & $238 \pm 44$ & $849 \pm 195^{*}$ \\
\hline
\end{tabular}

a Binding conditions are as described for the experiments indicated in Figure 2, with 12 pM [ $\left.{ }^{3} \mathrm{H}\right]$ FMLP.

${ }^{b}$ Refers to number of separate experiments.

$* P<0.05$, comparing right and left hand columns.

macrophages can be ascribed to a lack of surface receptors.

\section{DISCUSSION}

Functional responses to FMLP have been described in neutrophils from a wide variety of species such as rat, rabbit, horse, guinea pig, and human $[3,8,12,27,32,40$, $42,50,54]$. These responses correlate with the presence of specific formylated peptide receptors on the cell surface $[1,29,42,51]$. In general these receptors are of relatively high affinity $\left(K_{D}\right.$ of $\left.1-30 \mathrm{nM}\right)$ with $10^{3}-10^{5}$ binding sites per cell. In contrast, no functional responses were found in neutrophils from the cat $[13,19]$, dog $[35,45]$, cow $[5,18]$, sheep [52], or pig [16,36]. Ligand binding studies suggest that canine and porcine neutrophils lack FMLP receptors $[16,45]$. Whether neutrophils from the cat, cow, or sheep have similar deficits in receptor expression remains to be determined. As has been shown in equine neutrophils, the lack of a single response to FMLP (e.g., chemotaxis) does not necessarily correspond to a lack of surface FMLP receptors [42].

The activity of formylated peptides on monocytes and macrophages is not as well reported, with FMLP responses in human and guinea pig alveolar macrophages being the best described $[14,22,30]$. Our report has shown that, while FMLP receptors are present on rat neutrophils, resident and elicited macrophages in the same animals lack this receptor. Rat macrophages have recently been shown to be capable of being primed for enhanced $\mathrm{O}_{2}{ }^{-}$responses to immune complexes after contact with PAF, ionomycin, or phorbol myristate acetate (PMA) [21]. Using the same protocols we have failed to find evidence for increased binding of $\left[{ }^{3} \mathrm{H}\right]$ FMLP (data not shown), suggesting that cryptic receptors for FMLP do not exist in rat alveolar macrophages. Our study indicates that FMLP receptor expression on neutrophils is not predictive of receptor expression on other cell types within the same species. 
Although FMLP has biological activity in vivo in the dog and cat, whose neutrophils lack an FMLP response $[24,47]$, this activity is probably not related to direct effect of FMLP on the neutrophil and may reflect that FMLP first activates another cell type, products of which can then activate neutrophils.

The absence of a chemotactic receptor for bacterial peptides would be expected to be a biological disadvantage since alveolar macrophages represent the first line of defense in combating airborne infections. The rat does not appear to be unique since, in preliminary experiments, mouse macrophages also do not respond to FMLP with increases in intracellular $\mathrm{Ca}^{2+}$ (data not shown). The lack of response to the formylated peptides tested may be of no functional significance in vivo. It is possible that a response to another combination of formylated peptides or entirely different chemoattractants/stimulants (e.g., C5a) compensates for this selective defect $[16,17,28,44]$. Alternatively, insensitivity to the bacterial chemotactic peptides may be an adaption by some rodent species which are constantly exposed to bacterial aerosols because of their habitat. This insensitivity may prevent repeated macrophage activation leading to chronic lung injury and fibrosis. On the basis of these observations, in vivo inflammatory responses to FMLP may reflect the engagement of complex inflammatory cascades, some resulting in indirect stimulation of inflammatory cells, rather than a direct activation by FMLP of inflammatory cells.

\section{ACKNOWLEDGMENTS}

This work was supported in part by NIH grant HL31963, HL-07517, and GM-29507.

We wish to acknowledge the invaluable contribution of Kimberly D. Drake and Jennifer L. Fricke in the preparation of this manuscript.

\section{REFERENCES}

1. Aswanikumar, S., Corcoran, B., Schiffman, E., Day, A.R., Freer, R.J., Showell, H.J., Becker, E.L., and Pert, C.B. Demonstration of a receptor on rabbit neutrophils for chemotactic peptides. Biochem. Biophy. Res. Commun. 74,810, 1977.

2. Basilion, J.P., Stickle, D.F., and Holian, A. Extracellular hydrolysis of formyl peptides and subsequent uptake of liberated amino acids by alveolar macrophages. Biochem. Biophys. Acta. $886,255,1986$.

3. Becker, E.L. A multifunctional receptor on the neutrophil for synthetic chemotactic oligopeptides. J. Reticuloendothel. Soc. 26 (Suppl), 701, 1979.

4. Becker, E.L., Kermode, J.C., Naccache, P.H., Yassin, R., Munoz, J.J., Marsh, M.L., Huang, C.K., Sha'afi, R.I. Pertussis toxin as a probe of neutrophil activation. Federation Proc. 45,2151, 1986.

5. Bender, J.G., McPhail, L.C., and Van Epps, D.E. Exposure of human neutrophils to chemotactic factor potentiates activation of the respiratory burst enzyme. J. Immunol. 130,2317, 1983.
6. Bentwood, B.J., and Henson, P.M. The sequential release of granule constituents from human neutrophils. J. Immunol. $124,855,1980$.

7. Benyunes, M.C., and Snyderman, R. Characterization of an oligopeptide chemoattractant receptor on human blood monocytes using a new radioligand. Blood 63,58, 1984.

8. Boukili, M.A., Bureau, M.-F., Lellouch-Tubinana, A., Lefort, J., Simon, M-T., and Varayaftig, B.B. Alveolar macrophages and eicosanoids but not neutrophils, mediate bronchoconstriction induced by FMLP in the guinea-pig. Br. J. Pharmacol. 98,61, 1989.

9. Boxer, L.A., Yoder, M., Bonsib, S., Schmidt, M., Ho, P., Jersild, R., and Baehner, R.L. Effects of a chemotactic factor, $\mathrm{N}$-formyl methionyl peptide, on adherence, superoxide anion generation, phagocytosis and microtubule assembly of human polymorphonuclear leukocytes. J. Lab. Clin. Med. 93,506, 1979.

10. Bradford, P.G., and Rubin, R.P. Characterization of formyl methionyl-leucyl-phenylalanine stimulation of inositol trisphosphate accumulation in rabbit neutrophils. Mol. Pharmacol. 27,74, 1985.

11. Bradford, P.G., and Rubin, R.P. Quantitative changes in inositol 1,4,5-trisphosphate in chemoattractant-stimulated neutrophils. J. Biol. Chem. 261,15644, 1986.

12. Chandler, D.E., and Katzilek, C.J. Chemotactic peptide-induced exocytosis in neutrophils: granule fusion patterns depend on the source of messenger calcium. J. Cell Sci. 83,293, 1986.

13. Chenoweth, D.E., Lane, T.A., Rowe, J.G., and Hugli, T.E. Quantitative comparisons of neutrophil chemotaxis in four animal species. Clin. Immunol. Immunopathol. 15,525, 1980.

14. Diamond, M.S., and Holian, A. Biochemical properties of macrophage fractions and their relation to the mechanism of superoxide production. FEBS Lett. 197,21, 1986.

15. Fletcher, M.P., Seliymann, B.E., and Gallin, J.I. Correlation of human neutrophil secretion, chemoattractant receptor mobilization, and enhanced functional capacity. J. Immunol. 128,941, 1982.

16. Fletcher, M.P., Stahl, G.L., and Longhurst, J.C. In vivo and in vitro assessment of porcine neutrophil activation responses to chemoattractants: flow cytometric evidence for the selective absence of formyl peptide receptors. J. Leukoc. Biol. 47,355, 1990.

17. Granger, D.N., Zimmermann, B.J., Sekizuka, E., and Girsham, M.B. Intestinal microvascular exchange in the rat during luminal perfusion with formyl-methionyl-leucyl-phenylalaine. Gastroenterology 94,673, 1988.

18. Gray, C.D., Knight, K.A., Nelson, R.D., and Herron, M.J. Chemotactic requirements of bovine leukocytes. Am. J. Vet. Res. 43,757, 1982.

19. Gray, G.D., Ohlmann, G.M., Morton, D.R., and Schaub, R.G. Feline polymorphonuclear leukocytes respond chemotactically to leukotriene B4 and activated serum but not F-met-leu-phe. Agents Action 18,401, 1986.

20. Grynkiewiez, G., Poenie, M., and Tsien, R.Y. A new generation of $\mathrm{Ca}^{2+}$ indicators with greatly improved fluorescence properties. J. Biol. Chem. 260,3440, 1985.

21. Hagenlocker, B.E., Walker, B.A.M., and Ward, P.A. Superoxide responses in immune complex rat alveolar macrophages: intracellular calcium and priming. J. Immunol. 144,3898, 1990.

22. Hirata, M., Hashimoto, T., Hamachi, T., and Koga, T. Changes in intracellular free $\mathrm{Ca}^{2+}$ in macrophages following $\mathrm{N}$-formyl chemotactic peptide stimulation: direct measurement by the loading of Quin 2. J. Biochem. 96,9, 1984.

23. Honeycutt, P.J., and Niedel, J.E. Cytochalasin B enhancement of the diacylglycerol response in formyl peptide-stimulate neutrophils. J. Biol. Chem. 261,15900, 1986.

24. House, S.D., and Lipowsky, H.H. Leukocyte-endothelium adhe- 
sion: microhemodynamics in mesentery of the cat. Microvasc. Res. 34,363, 1987.

25. Korchak, H.M., Vienne, K., Rutherford, L.E., Wilkenfeld, C., Finkelstein, M.C., and Weissman, G. Stimulus response coupling in the human neutrophil: II temporal analysis of changes in cytosolic calcium and calcium efflux. J. Biol. Chem. 259,4076, 1984.

26. Korchak, H.M., Vosshall, L.B., Haines, K.A., Wilkenfeld, C., Lundquist, K.F., and Weissman, G. Activation of the human neutrophils by calcium-mobilizing ligands: II correlation of calcium, diacyl glycerol and phosphatidic acid generation with superoxide anion generation. J. Biol. Chem. 263,11098, 1988.

27. Lehmeger, J.E., Snyderman, R., and Johnston, R.B., Jr. Stimulation of neutrophil oxidative metabolism by chemotactic peptides: influence of calcium ion concentration and cytochalasin B and comparison with stimulation of phorbol myristate acetate. Blood 54,35, 1979.

28. Magnusson, K.-E., Dahlgren, C., and Sjolander, A. Effect of $\mathrm{N}$-formylated methionyl-phenylalanine (FMP) and methionylleucyl-phenylalanine (FMLP) on gut permeability: a model of local inflammatory process. Inflammation 9,365, 1985.

29. Marasco, W.A., Fantone, J.C., Freer, R.J., and Ward, P.A. Characterization of the rat neutrophil formyl peptide chemotaxis receptor. Am. J. Pathol. 111,273, 1983.

30. Nakashima, H., Ando, M., Sugimoto, M., Suga, M., Soda, K., and Shukuro, A. Receptor-mediated O2-release by alveolar macrophages and peripheral blood monocytes from smokers and nonsmokers: priming and triggering effects of monomeric IgG, concanavalin A, N-formyl-methionyl-leucyl-phenylalanine, phorbol myristate acetate and cytochalasin D. Am. Rev. Respir. Dis. 136,310, 1987.

31. Niedel, J., Wilkinson, S., and Cuatreeasas, P. Receptor-mediated uptake and degradation of ${ }^{125}$ I-chemotactic peptide by human neutrophils. J. Biol. Chem. 254,10700, 1979.

32. Olsen, U.B., and Bille-Hansen, V. Endotoxin pretreatment enhances neutrophil FMLP-receptor binding and activity in guinea pigs. Agents Action 21,177, 1987.

33. Onyia, K.A. In vivo chemotaxis of rat leukocytes to $\mathbf{N}$-formylL-methionyl-L-leucyl-L-phenylalanine (FMLP). Comp. Immunol. Microbiol. Infect. Dis. 10,33, 1987.

34. Petrequin, P.R., Todd, R.F., III, Devall, L.J., Boxer, L.A., and Curnutte, J.T., III. Association between gelatinase release and increased plasma membrane expression of the Mol glycoprotein. Blood 69,605, 1987.

35. Redl, H., Flynn, P.J., Lamche, H., Schiesser, A., Schlag, G., and Hammerschmidt, D.E. Aggregation, chemotaxis and chemiluminescence of canine granulocytes: studies utilizing improved cell preparation techniques. Inflammation 7,67, 1983.

36. Roberts, R.L., Hatori, N., Grury, J.K., and Stiehm, E.R. Purification and properties of porcine polymorphonuclear cells. J. Immunol. Methods 103,27, 1987.

37. Rossi, F., Bianca, V.D., Grzeskowiak, M., De Togni, P., and Cabrini, G. Relationships between phosphoinositide metabolism, $\mathrm{Ca}^{2+}$ changes and respiratory burst in formyl-methionyl-leucylphenylalanine-stimulated human neutrophils. FEBS Lett. $181,253,1985$.

38. Schiffmann, E., Corcoran, B.A., and Wahl, S.M. Formyl methionyl peptides as chemoattractants for leukocytes. Proc. Natl. Acad. Sci. USA 72,1059, 1975.

39. Schiffmann, E., Showell, H.J., Corcoran, B.A., Ward, P.A., Smith, E., and Becker, E.L. The isolation and partial character- ization of neutrophil chemotactic factors from $E$. Coli. J. Immunol. $114,1831,1975$

40. Showell, H.J., Freer, R.J., Zigmond, S.H., Schiffman, E., Aswanikumar, S., Corcoran, B., and Becker, E.L. The structureactivity relations of synthetic peptides as chemotactic factors and inducers of lysosomal enzyme secretion for neutrophils. J. Exp. Med. 143,1154, 1976.

41. Smolen, J.E., Korchak, H.M., and Weissman, G. Increased levels of cyclic adenosine-3' ${ }^{\prime}$ '-monophosphate in human polymorphonuclear leukocytes after surface stimulation. J. Clin. Invest. $65,1077,1980$.

42. Snyderman, R., and Pike, M.C. N-formylmethionyl peptide receptors on equine leukocytes initiate secretion but not chemotaxis. Science 209,493, 1980.

43. Snyderman, R., Pike, M.C., Edge, S., and Lane, B. A chemoattractant receptor on macrophages exists in two affinity states regulated by guanine nucleotides. J. Cell Biol. 99,444, 1984.

44. Soland, L.C., Van Epps, D.E., Maez, D., Gutierrez, L., and Samora, A. Acute infusion of chemotactic of enkephalin-analog peptides into rat cerebral ventricles: scanning and transmission electron microscopy of leukocyte immigration in vivo. J. Neuroimmunol. 18,197, 1988

45. Stickle, J.E., Kwan, D.K-H., and Smith, C.W. Neutrophil function in the dog: shape change and response to a synthetic tripeptide. Am. J. Vet. Res. 46,225, 1985

46. Tennenberg, S.D., and Solomkin, J.S. Activation of neutrophils by cachectin/tumor necrosis factor: priming of $\mathrm{N}$-formyl-methranyl-leucyl-phenylalanine-induced oxidative responsiveness via receptor mobilization without degranulation. J. Leukoc. Biol. 47,217, 1990

47. Turner, C.R., Kolbe, J., and Spannhake, E.W. Rapid increase in mast cell numbers in canine central and peripheral airways. J. Appl. Physiol. 65,445, 1988.

48. Ward, P.A., Cunningham, T.W., McCulloch, K.K., and Johnson, K.J. Regulatory effects of adenosine and adenine nucleotides on oxygen radical responses of neutrophils. Lab. Invest. 58,438, 1988

49. Ward, P.A., Lepow, I.H., and Newman, L.J. Bacterial factors chemotactic for polymorphonuclear leukocytes. Am. J. Pathol. $52,725,1968$

50. Warren, J.S., Kunkel, R.G., Johnson, K.J., and Ward, P.A. Comparative $\mathrm{O}_{2}^{-}$-responses of lung macrophages and blood phagocytic cells in the rat: possible relevance to IgA immune complex induced lung injury. Lab. Invest. 57,311, 1987.

51. Williams, L.T., Snyderman, R., Pike, M.C., and Lefkowitz, R.J. Specific receptor sites for chemotactic peptides on human polymorphonuclear leukocytes. Proc. Natl. Acad. Sci. USA 74,1204, 1977.

52. Young, S., and Beswick, P. A comparison of the oxidative reactions of neutrophils from a variety of species when stimulated by opsinized zymosan and F-Met-Leu-Phe. J. Comp. Pathol. $96,189,1986$

53. Zigmond, S.H. Consequences of chemotactic peptide receptor modulation for leukocytes orientation. J. Cell. Biol. 88,644, 1981.

54. Zimmerli, W., Seligmann, B., and Gallin, J.I. Exudation primes human and guinea pig neutrophils for subsequent responsiveness to the chemotactic peptide $\mathrm{N}$-formyl methionylleucylphenylalanine and increases complement component $\mathrm{C} 3 \mathrm{bi}$ receptor expression. J. Clin. Invest. 77,925, 1986. 